\title{
Domestic Westward Expansion in Mainland China Causes, Effects, Foreign Investment, and Local Regulations
}

\author{
Paul Kossof ${ }^{1}$ \\ ${ }^{1}$ The John Marshall Law School, Chicago, United States \\ Correspondence: Paul Kossof, The John Marshall Law School, Chicago IL, 60093, United States. Tel: \\ 1-847-507-9007. E-mail: pauljkossof@gmail.com
}

Received: September 10, 2013 Accepted: October 13, 2013 Online Published: October 31, 2013

doi:10.5539/ilr.v2n1p156

URL: http://dx.doi.org/10.5539/ilr.v2n1p156

\section{Introduction}

Kunming City, the capital of Yunnan Province, is known through the People's Republic of China (hereinafter "PRC") for its beautiful gardens and scenery. ${ }^{1}$ Recently, tourists are not the only people visiting this Southwestern city. Kunming is undergoing rapid expansion as companies from throughout the PRC and abroad enter the local economy. ${ }^{2}$ This relatively small capital now has Apple Stores, Louis Vuitton, and Starbucks. ${ }^{3}$ Surprisingly, most of the foreign luxury car companies have also entered Kunming. Ferraris, Lamborghinis, and Mercedes are now a common sight in the PRC's "Spring City.",

This article discusses domestic westward economic expansion in the PRC. In the context of the PRC's progress towards a developed and globalized society, this article focuses on foreign participation and examines the effects of expansion on developing areas in Western China and more developed areas in Eastern China. This article also explores local regulations that affect foreign investment and local expansion. This article begins by examining the current extent of foreign manufacturing and sales in the PRC, the causes and effects of domestic westward expansion, and the local regulations that either promote foreign investment or protect society and the environment from the adverse effects of rapid development. This article then analyzes local regulations, the current economic situation in Eastern China, and the future of Western China. This article concludes by providing insight on the effectiveness of local regulations and the relationship between foreign companies and Western China.

\subsection{Background}

Part A of this section briefly discusses the presence of foreign companies in the PRC; Part B examines the economic causes behind westward expansion; Part $\mathrm{C}$ explores selected regulations from Chongqing City, Sichuan Province, and Chengdu City; Part D investigates the economic effects of westward expansion on both Western China and Eastern China.

\subsubsection{Foreign Companies in the PRC}

\section{(1). General Overview}

Foreign companies have relied heavily on the PRC for their manufacturing needs primarily due to inexpensive labor costs. ${ }^{5}$ The PRC is also an attractive manufacturing location due to its educated labor force, stable and affordable energy, and export rebates. ${ }^{6}$ Despite increasing labor costs, the PRC continues to be competitive with

\footnotetext{
1 See, e.g., Kunming Attractions - Kunming Sightseeing List, ChinATourOnLINE.COM, http://www.chinatouronline.com/china-travel/kunming/kunming-attractions/index.html (last visited Apr. 17, 2013).

2 Patrick Scally, Yunnan's Economy Outpacing National Average, Go KunMING (Apr. 18, 2013), http://www.gokunming.com/en/blog/item/2675/yunnans_economy_outpacing_national_average.

3 See, e.g., Hilton, Starbucks to Expand Investment in Kunming, InKunming (Oct. 19, 2011), http://en.kunming.cn/index/content/2011-10/19/content_2702460.htm.

4 See World's Luxury Car Brands Focus on Kunming Int'l Auto Show, InKunMing (June 17, 2011), http://en.kunming.cn/index/content/2011-06/17/content_2565292.htm; see also Kunming, CHINAVISTA.COM, http://www.chinavista.com/travel/kunming/part0.html (last visited Apr. 17, 2013).

${ }^{5}$ See, e.g., Manufacturing in China, U.S. BUREAu OF LAB. STAT. (Apr. 4, 2011), http://www.bls.gov/fls/china.htm\#charts.

${ }^{6}$ See Greg Tyng et al., China Manufacturing Cost Competitiveness, George Washington U. (Mar. 27, 2009), pgs. 3-4, available at http://elliott.gwu.edu/assets/docs/acad/itip/global_insight.pdf.
} 
other developing Asian countries. ${ }^{7}$ In fact, the PRC produces the majority of many of the world's products. ${ }^{8}$ As of 2010, 98 of the Fortune 500 companies had research and development facilities located in the PRC. ${ }^{9}$ At that time, 300,000 foreign companies had invested in the PRC. ${ }^{10}$ By June, 2012, the number of foreign-funded companies rose to $436,800 .^{11}$

Foreign companies are also ramping up their domestic sales efforts as the PRC's economy continues to develop. The decade has seen a substantial shift in the number of foreign stores and products in the PRC. ${ }^{12}$ Carrefour and Wal-Mart have strong presences throughout Western and Eastern China. ${ }^{13}$ Foreign luxury goods stores are in every major city. ${ }^{14}$ The PRC has become the largest luxury goods consumer due to its extremely wealthy upper-class and expanding middle-class. ${ }^{15}$ Luxury brands including Burberry and Armani have opened e-commerce stores in the PRC. ${ }^{16}$ Foreign companies are beginning to diversify their products in order to attract Chinese consumers. For example, luxury car companies such as BMW have even opened their own design studios. ${ }^{17}$ Many domestic and foreign companies are also shifting their investments into Western China. ${ }^{18}$

\section{(2). Foreign Presence in Western China}

Foreign Direct Investment (hereinafter "FDI") tripled in Western China from 2006 to 2011. ${ }^{19}$ Western China's FDI in 2011 rose four times faster than in Eastern China. ${ }^{20}$ In April, 2012, Samsung announced its plan to invest seven billion USD on a new plant in Xi'an City. ${ }^{21}$ One of the primary factors that played into its decision was the provincial government's cooperation. ${ }^{22}$ Local governments in Western China increase FDI through incentives such as tax breaks. ${ }^{23}$ Certain industries that have not yet developed such as insurance could be especially profitable to foreign firms. ${ }^{24}$ Local governments also welcome foreign banks, private equity, and fund management firms. ${ }^{25}$ Foxconn has opened factories in Western China in order to avoid the increased labor costs in

\footnotetext{
7 See 2011 Report: China manufacturing hourly labor rate, compensation costs impact EMS, VENTURE OUTSOURCE (Apr. 17, 2011), $\mathrm{http} / /$ www.ventureoutsource.com/contract-manufacturing/2011-china-manufacturing-hourly-labor-rate-compensation-costs-ems (showing that Chinese labor continues to compete with India and the Philippines).

${ }^{8}$ See, e.g., China Manufacturing Statistics, StAT. BRAIn, http://www.statisticbrain.com/china-manufacturing-statistics/ (last visited Apr. 4, 2013).

9 Jeffrey Hays, Foreign Companies and Foreign Investment in China, FACTSANDDETAILS.COM (Apr. 2012), http://factsanddetails.com/china.php?itemid=349.

${ }^{10}$ Id.

11 Foreign-funded Companies Total436,800 in China, CHINA DAILY (Sept. 22, 2012), http://www.chinadaily.com.cn/bizchina/2012-09/22/content_15775312.htm.

${ }_{12}$ See, e.g., Here Come More Foreign Shops, XZBU.Com (Dec. 23, 2012), http://www.xzbu.com/2/view-3813818.htm.

13 See Diao Ying, Foreign Retailers Bank Hopes on China, ChinA DAILY (Sept. 28, 2012), http://usa.chinadaily.com.cn/weekly/2012-09/28/content_15789285.htm.

${ }^{14}$ See, e.g., Jeffrey Hays, Luxury Goods in China, FACTSANDDETAILS.COM (Aug. 2012), http://factsanddetails.com/china.php?itemid=1889.

${ }^{15}$ Yuval Atsmon et al., Luxury Without Borders: China's New Class of Shoppers Take on the World, MCKINSEY \& Co. (Dec. 2012), available

http://www.google.com.hk/search?hl=zh-CN\&safe=strict\&client=firefox-a\&hs=im3\&rls=org.mozilla\%3Azh-CN\%3Aofficial\&source=lnt\&b iw $=1025 \&$ bih $=443 \&$ tbs $=$ qdr\%3 Ay\&q=luxury+stores + in + china\&oq=luxury+stores + in + china\&gs $1=$ serp.3...320832.323643.0.323803.26.21. 2.0.0.0.104.1414.19j2.21.0...0.0...1c.1.4.serp.qU1I1yLRfv8.

${ }^{16} I d$. at pg. 28.

17 See Dan Neil, The Ferrari with the Dragon Tattoo, WALL ST. J. (May 10, 2012), http://online.wsj.com/article/SB10001424052702304050304577378032548853036.html.

18 See Dan Steinbock, Foreign Investment Relocates in China and Asia, EconoMonitor (Feb. 27, 2013), http://www.economonitor.com/blog/2013/02/foreign-investment-relocates-in-china-and-asia/.

19 See Foreign Direct Investment Continues to Expand West, Wordpress.com (July 23, 2012), http://chinacentric.wordpress.com/2012/07/23/foreign-direct-investment-continues-to-expand-west/.

20 Foreign Investors Warm to Western Region, CHINA DAILY (May 23, 2012), available at http://www.china.org.cn/business/2012-05/23/content_25451754.htm.

${ }^{21}$ Foreign Direct Investment Continues to Expand West, supra note 19.

22 See Ding Qingfen, Foreign Firms Finding New Fields, ChinA DAILY (May 23, 2012), http://www.chinadaily.com.cn/business/2012-05/23/content_15363039.htm.

23 See Claire Rumbellow, Why More Foreign Companies Should Invest in South-West China, THE CHINA Times, http://www.thechinatimes.com/online/2012/09/5144.html (last visited Feb. 26, 2013).

${ }^{24}$ See id.

25 Ambrose Evans-Pritchard, China's 'Go West' Boom Offers Bonanza for British Banks, The Telegraph (Nov. 23, 2012), http://www.telegraph.co.uk/finance/china-business/9698763/Chinas-Go-West-boom-offers-bonanza-for-British-banks.html.
} 
Eastern China. ${ }^{26}$ Western China also attracts FDI due its attractive corporate regulations. For example, the business duration of a wholly foreign-owned enterprise (hereinafter "WFOE") in Western China is ten years longer than its Eastern counterpart. ${ }^{27}$ It should be noted, however, that local incentives are not the principal reason for the increase in Western China's FDI.

\subsubsection{Effect of Eastern China's Economy on Westward Expansion}

Foreign manufacturing is moving into Western China because of Eastern China's development. ${ }^{28}$ There are three primary factors in Eastern China that influence whether a foreign company will relocate into Western China: labor, land, and standards of living. ${ }^{29}$

\section{(1). Labor Costs}

The increasing cost of labor in Eastern China is the most influential factor on foreign relocation. ${ }^{30}$ In 2012 , a survey of foreign manufacturers in the Pearl River Delta ${ }^{31}$ reported that labor costs rose ten percent in the previous year. ${ }^{32}$ Some companies are reporting up to 20 percent increases for the past four years. ${ }^{33}$ Labor costs in the PRC are now the third highest of all of the developing Asian countries, behind Malaysia and Thailand. ${ }^{34}$ Although the PRC has exhibited higher labor costs than most Southeast Asian countries for more than a decade, its costs began to increase dramatically in $2007 .{ }^{35}$ However, even if its minimum wage were to increase 30 percent a year, the rise in labor costs would only result in a one to five percent decrease in profits because labor costs are only one of the factors that affect profitability. ${ }^{36}$ Therefore, despite steadily rising labor costs, it is unlikely that the majority of foreign companies will suddenly abandon manufacturing in Eastern China. ${ }^{37}$ Rather, foreign companies will gradually shift their manufacturing focus to Western China and Southeast Asia. ${ }^{38}$

\section{(2). Land Costs}

The PRC classifies land into different categories including residential, commercial, and industrial. ${ }^{39}$ Residential property in Eastern China's most populated cities is extremely expensive. ${ }^{40}$ However, the increase in residential property prices is beginning to slow down as local governments enact regulations in order to curb housing costs. ${ }^{41}$ In comparison, the PRC's commercial land continues to increase in value. ${ }^{42}$ Foreign companies are most interested in industrial land prices and whether local governments will provide low rent and tax rates. ${ }^{43}$ Although the cost of industrial land only increased 2.7 percent in $2012,{ }^{44}$ the cost of industrial land in Eastern China soared

\footnotetext{
${ }^{26}$ See id.

27 See Chris Devonshire-Ellis, China FICE vs. Manufacturing WFOE, ChINA BRIEFING (May 11, 2012), http://www.china-briefing.com/news/2012/05/11/china-fice-vs-manufacturing-wfoe.html (explaining that "[b]usiness duration is limited to 30 years for foreign trading companies set up in the developed coastal areas[;] Companies established in West China are allowed business duration of 40 years").

${ }^{28}$ The End of Cheap China, THE ECONOMIST (Mar. 10, 2012), http://www.economist.com/node/21549956.

${ }^{29}$ See id.

${ }^{30}$ See id.

${ }^{31}$ The Pearl River Delta is a system of rivers and tributaries in Guangdong Province, and is one of the main economic areas in the PRC.

32 The End of Cheap China, supra note 28.

${ }^{33}$ See, e.g., id.

${ }^{34}$ Chris Devonshire-Ellis, China Now Has Third Highest Labor Costs in Emerging Asia, AsIA BriEfing (Jan. 19, 2011), http://www.china-briefing.com/news/2011/01/19/china-near-top-of-the-list-for-wage-overheads-in-emerging-asia.html.

${ }^{35}$ See Jonathan Wright et al., Wage Increases in China: Should Multinationals Rethink their Manufacturing and Sourcing Strategies?, ACCENTURE (2011), pg. 9, available at http://www.accenture.com/SiteCollectionDocuments/PDF/Accenture_Wage_Increases_in_China.pdf.

${ }^{36}$ See id. at pg. 4.

37 See id.

38 See, e.g., Yajun Zhang, China Begins to Lose Edge as World's Factor Floor, WALL ST. J. (Jan. 16, 2013), http://online.wsj.com/article/SB10001424127887323783704578245241751969774.html.

39 See Jianquan Cheng et al., Urban Land Administration and Planning in China: Opportunities and Constraints of Spatial Data Models, SCIENCE DIRECT (May 23, 2005), available at mearc.eu/resources/LUPTurkstraHo.pdf.

40 See, e.g., Beijing Residential Land Prices Drop to 2009 Levels, ChinA DAILy (July 14, 2012), http://www.chinadaily.com.cn/business/2012-07/14/content_15580686.htm.

${ }^{41}$ See, e.g., id.

42 See Yu Fenghui, Commercial Property Market a Bubble Waiting to Explode, PeOPle's DaILY OnLINE (July 13, 2012), http://english.peopledaily.com.cn/90778/7874187.html.

43 See, e.g., Tips and Market Trends for China['s] Industrial Zone[s], BusINESS-IN-ASIA.COM, http://www.business-in-asia.com/china/china_ip.html (last visited Apr. 17, 2013).

44 Residential Land Prices Up 2.26\% in 2012, ChINA DAILY (Jan. 15, 2013),
} 
from 11 USD to 21 USD per square foot. ${ }^{45}$ Generally, local governments seeking to promote FDI will often provide an investor with inexpensive or free industrial land. ${ }^{46}$ However, Eastern China has already stopped granting large incentives to foreign investors. Instead, industrial land prices continue to rise as local governments implement new taxes and even reclaim land. ${ }^{47}$ Consequently, foreign companies are becoming increasingly aware of Western China's local incentives.

\section{(3). Standard of Living}

The third factor that affects the determination of whether to move manufacturing out of Eastern China is standard of living. The average factory worker in Eastern China has a higher standard of living than a factory worker with a similar position in Western China. The standard of living in Eastern China is a direct result of its economic development. ${ }^{48}$ Additionally, local governments in Eastern China have implemented more regulations due to local development. ${ }^{49}$ These regulations address issues such as food safety, housing regulations, employees' rights, and corruption. ${ }^{50}$ Although the higher standard of living is certainly beneficial to the general population, it also affects manufacturing costs. For example, workers require higher salaries because food safety regulations drive up food prices. ${ }^{51}$ A greater percentage of workers in Eastern China enter into employment contracts and strike. ${ }^{52}$ As a result, these workers receive more protection than other workers. The construction industry is a good example of how corruption actually reduces initial costs. Public officials may receive bribes from contractors and, in return, allow them to falsify their building material records. ${ }^{53}$ This allows contractors to build less expensive, albeit more dangerous, buildings. ${ }^{54}$ However, although corruption reduces initial costs, cheap building materials cause additional expenses such as repairs, heat loss, electrical failures, fires, etc. ${ }^{55}$

The higher standard of living factor includes the other factors such as labor and land. Developed areas generally have higher standards of living, and Eastern China is no exception to this rule. Eastern China has already outgrown its period of rapid development when it would sacrifice its workers and natural resources for investment and growth. As Eastern China continues to become progressively more expensive, local governments in Western China are seizing their opportunity to attract investment and stimulate development.

\subsubsection{Local Regulations}

Local governments in Western China have begun to implement regulations due to increased investment from outside their local areas. These regulations function to either promote and regulate the economy or to protect society from the adverse effects of development. Foreign companies should have a basic understanding of the types of local government regulations before they move manufacturing operations into Western China. This section translates key measures from Chongqing City, Sichuan Province, and Chengdu City regulations in order to show how municipal and provincial legislation has an effect on outside investment. This article discusses the measures from Chongqing and Chengdu because they are the largest and most rapidly developing cities in Western China. Chongqing is a self-autonomous city, ${ }^{56}$ which has both municipal and provincial powers, and Sichuan has provincial power over Chengdu.

\footnotetext{
http://www.chinadaily.com.cn/china/2013-01/15/content_16122176.htm.

45 Mike King, Rising Labor Costs, Land Prices Challenge China's Competitiveness, THE J. OF CoM. (May 4, 2012), http://www.joc.com/economy-watch/rising-labor-costs-land-prices-challenge-china\%E2\%80\%99s-competitiveness_20120504.html.

46 Enar Lazcano, Industrial Relocation of Foxconn, CEIBS (2009), pg. 6, available at http://www.ceibs.edu/bmt/images/20110221/30206.pdf.

47 See id. at pg. 7.

48 The Chinese Economy, ECONOMY WATCH (June 30, 2010), http://www.economywatch.com/world_economy/china/?page=full.

49 See, e.g., More Regulation Possible as House Prices Rise, CHINA DAILY (Aug. 24, 2012), www.chinadaily.com.cn/china/2012-08/24/content_15703269.htm.

${ }^{50}$ See id.

51 See Food Costs Threaten Rebound in China, THE NEW York TIMES (Mar. 11, 2013), http://www.nytimes.com/2013/03/12/business/global/food-costs-threaten-rebound-in-china.html

${ }_{52}$ See White Collar Workers Lose Out as Factory Wages Rise in the Pearl River Delta, China Labour Bulletin (Mar. 9, 2011), http://www.clb.org.hk/en/content/white-collar-workers-lose-out-factory-wages-rise-pearl-river-delta.

53 See Corruption Still Rife in Construction Industry, ChINA DAILY (Oct. 19, 2011), http://www.chinadaily.com.cn/cndy/2011-10/19/content_13929295.htm

${ }^{54}$ See, e.g., Jeffrey Hays, Infrastructure in China: Bridges, Large Project and Bean Curd Construction, FACTSANDDETAILS.COM (Nov. 2011), http://factsanddetails.com/china.php?itemid=326\&catid=12.

55 See, e.g., Fonua Talei, Cheap Building Materials a Concern, FiJI Sun (Oct. 13, 2012), http://www.fijisun.com.fj/2012/10/13/cheap-building-materials-a-concern-says-nfa/
}

56 Chongqing is one of the four “直辖市” (zhixiashi), which means “centrally administered municipality." The other centrally 


\section{(1). Chongqing City}

\section{a. Promotion and Regulation of Economy}

This section covers the primary regulations that Chongqing has enacted in order to promote and regulate its economy. In 2008, the Chongqing Municipal People's Congress enacted the Measures of Chongqing Municipality on the Promotion of Development. ${ }^{57}$ These measures are the general backbone for related legislation and actions by local administrations for industry and commerce (hereinafter "AICs"). Their purpose is to promote rapid and healthy development within the city. ${ }^{58}$ They begin by directing each of the city's governmental institutions and organizations to focus their efforts on expanding the local economy. ${ }^{59}$ They then designate duties for local governments and AICs. ${ }^{60}$

The municipal and county-level governments must promote the city's economy by providing aid to local enterprises and complying with the needs of the local business community ${ }^{61}$ County-level governments should establish a forum related to local investment. ${ }^{62}$ This forum will provide information related to investment and discourage local monopolies. ${ }^{63}$ Local governments must also promote expansion by participating in the international market and allowing FDI. ${ }^{64}$ These measures also refer to several activities that local governments should support such as manufacturing, exports, and research associated with economic expansion. ${ }^{65}$

These measures further state that local governments must do more than facilitate the expansion of Chongqing's economy. They should also incorporate investment into their budgets. ${ }^{66}$ Local governments should focus their efforts on companies that are either established by Chinese citizens with experience abroad or that are related to new and advanced technology ${ }^{67}$ On the other hand, local governments must conduct careful due diligence if they intend to invest in banks, insurance companies or venture capital firms. ${ }^{68}$ These measures provide how local governments should regulate their promotion of the economy. For example, they suggest that local governments should focus on the legality of the investments made by private citizens, and suggest that they share information amongst themselves in order to learn from their mutual experiences. ${ }^{69}$ These measures provide detailed information as to how local governments should promote expansion in Chongqing. Lower-level local governments interpret some of these duties as suggestions rather than requirements. As a result, the Chongqing legislature also enacted specific measures related to the expansion of the city's economy.

The Chongqing Municipal People's Congress enacted another piece of legislation on the same date as the general measures discussed above. This regulation is called the Measures of Chongqing Municipality on the Promotion of Small and Medium Enterprises. ${ }^{70}$ These measures inform local governments and AICs how to promote small and medium enterprises (hereinafter "SMEs") and list the approved methods of local financial assistance. ${ }^{71}$ These measures include the duties of the municipal government such as that it must establish the city's procedures for the promotion of SMEs, procure funds for investing in these companies, and process any complaints that these companies have. ${ }^{72}$ The primary assistance that the local government provides to SMEs is investment. These

\footnotetext{
administered municipalities are Beijing, Shanghai, and Tianjin. Unlike other municipalities, which operate under provincial governments, centrally administered municipalities are not part of a province and, therefore, have both municipal and provincial powers.

57 See Chongqingshi Cujin Kaifang Tiaoli (重庆市促进开放条例) [Measures of Chongqing Municipality on the Promotion of Development] (promulgated by the Chongqing Municipal People's Congress, Nov. 27, 2008, effective Jan. 1, 2009).

${ }^{58}$ See id. art. 1.

${ }^{59}$ Id. art. 5 .

${ }^{60}$ See generally id.

${ }^{61}$ Id. art. 8 .

62 Id. art. 13.

${ }^{63} \mathrm{Id}$.

${ }^{64}$ See id. art. 14.

${ }^{65}$ See id. art. 15.

${ }^{66}$ Id. art. 20.

${ }^{67}$ See id. art. 22.

${ }^{68}$ Id. art. 25.

${ }^{69}$ See id. art. 38-39.

${ }^{70}$ See Chongqingshi Zhongxiao Qiye Cujin Tiaoli (重庆市中小企业促进条例) [Measures of Chongqing Municipality on the Promotion of Small and Medium Enterprises] (promulgated by the Chongqing Municipal People's Congress, Nov. 23, 2007, effective Jan. 1, 2008).

${ }^{71}$ See generally id.

${ }^{72}$ See id. art. 5.
} 
measures state that investment in a company may take the form of providing credit, being a guarantor for the company, and compensating for certain risk-associated losses. ${ }^{73}$

Municipal and county-level governments may also support SMEs by arranging land for their use. ${ }^{74}$ Local $^{2}$ governments may carve out certain land in their annual plans for companies. ${ }^{75}$ These measures also prioritize land use for rural collective economic organizations. ${ }^{76}$ In addition, local governments may support SMEs through tax exemptions. ${ }^{77}$ For example, SMEs may receive exemptions associated with training employees or conducting recruiting on campuses. ${ }^{78}$ Furthermore, local governments should prioritize SMEs in their dealings with large companies. $^{79}$ Although these measures prioritize SMEs over large companies in certain situations, Chongqing has also enacted regulations that promote its own larger companies.

The Measures of Chongqing Municipality on Famous Trademark Recognition and Protection were enacted in June, 2012. ${ }^{80}$ The purpose of these measures is to promote Chongqing's economy through the recognition and protection of its local famous trademarks. ${ }^{81}$ The owner of a local famous trademark has the right to advertise on a particular good that the good is associated with a famous mark. For example, products in Chongqing that have attained this mark always have “重庆著名商标” (Chongqing Famous Trademark) printed on their labels. Companies will also use this status to promote famous products on their websites and during live promotions. These measures only allow relatively large local companies to attain these marks because they require a local famous trademark applicant to be a frontrunner in its industry, have economic success, have used the mark continuously for at least three years, and reside in the city. ${ }^{82}$ A Chongqing local famous trademark is valid for three years, ${ }^{83}$ and local AICs must protect and strengthen local famous trademarks. ${ }^{84}$ The owner of a local famous trademark may request a local AIC to investigate another party if the owner reasonably believes it is infringing the company's rights. ${ }^{85}$ These measures further state that local AICs must investigate the possible infringement of a local famous trademark. ${ }^{86}$

The three measures mentioned in this section are the main regulations that Chongqing has enacted in order to promote its economy. All of these measures were passed in the last few years. As shown above, these measures give local governments and AICs a substantial amount of power to promote the local economy. They also allow Chongqing's local governments to make many of their own decisions. These measures show that the Chongqing legislature places a high priority on economic expansion. However, the legislature is also cognizant of the adverse effects of rapid development.

\section{b. Protections for Society and the Environment}

Chongqing has also enacted regulations to protect society and the environment from the adverse effects of development. The regulation that tackles this issue most directly is the Measures of Chongqing Municipality on the Promotion of Forest Expansion. ${ }^{87}$ The purpose of these measures is to promote the development of forests and improve Chongqing's environment. ${ }^{88}$ Surprisingly, these measures also state that they promote Chongqing's economy. ${ }^{89}$ They require that at least 45 percent of Chongqing's land is covered by forest, and that the urban areas

73 See id. art. 9.

74 See id. art. 16.

${ }^{75} \mathrm{Id}$.

${ }^{76}$ See id.

77 See id. art. 20.

78 See id. art. 33-34.

${ }^{79}$ Id. art. 26.

80 See Chongqingshi Zhuming Shangbiao Rending He Baohu Tiaoli (重庆市著名商标认定和保护条例) [Measures of Chongqing Municipality on Famous Trademark Recognition and Protection] (promulgated by the Chongqing Municipal People’s Congress, Sept. 22, 2011, effective June 1, 2012).

81 See id. art. 1 .

${ }^{82}$ Id. art. 7.

${ }^{83}$ Id. art. 15.

${ }^{84}$ Id. art. 18.

85 Id. art. 22.

${ }^{86}$ Id. art. 18.

${ }^{87}$ Chongqingshi Senlin Jianshe Cujin Tiaoli (重庆市森林建设促进条例) [Measures of Chongqing Municipality on the Promotion of Forest Expansion] (promulgated by the Chongqing Municipal People's Congress, July 23, 2010, effective Oct. 1, 2010).

${ }^{88}$ Id. art. 1.

${ }^{89} I d$. 
should be at least 39 percent forest. ${ }^{90}$ However, these measures do not state what percentage of Chongqing is covered by forest nor do they indicate the reasoning behind these percentages. ${ }^{91}$

Local governments must engage in activities that develop and protect forests. ${ }^{92}$ They should also promote green living, low-carbon usage, a green economy, and the establishment of an ecological and cultural society. ${ }^{93}$ Furthermore, they should encourage the use of more types of seeds, protect the fertility of the land, and prevent runoff. ${ }^{94}$ These measures state that the act of selling or moving ancient trees is illegal, ${ }^{95}$ and define ancient trees as over 100 years old.$^{96}$ Local governments should also plant trees along roads and railways. ${ }^{97}$ In addition, local governments have the responsibility of planting trees along their portion of highways. ${ }^{98}$ Local governments must also protect against forest fires and insects that harm forests. ${ }^{99}$ Finally, they should provide loans and mortgages to enterprises that seek to develop forests. ${ }^{100}$ Companies that engage in tree planting or seed production are also given corporate income tax exemptions and VAT exemptions. Although Chongqing has enacted regulations that cover natural resources such as forests, most of the regulations that protect society and the environment focus on regulating development. As a result, the Chongqing government has largely ignored local environmental concerns. ${ }^{101}$

An example of a regulation on economic development that improves the environment is the Measures of Chongqing Municipality on Energy-Saving Buildings. ${ }^{102}$ These measures apply to new construction, reconstruction, and expansion. ${ }^{103}$ They primarily regulate the materials and technology that buildings use in order to decrease the amount of heat lost in a building. ${ }^{104}$ They set the requirements for the departments of local AICs that control construction projects, and state that related departments must apply the national guidelines for energy-saving buildings when determining whether to grant a construction license. ${ }^{105}$ If a department determines that a proposed project does not satisfy national standards, then it cannot issue a construction license. ${ }^{106}$

These measures also place requirements on companies that sell corporate space. These companies are required to provide their clients with information regarding the technology that a building uses to save energy ${ }^{107}$ All of their sales contracts must include a five-year warranty for the insulation in the corporate space. ${ }^{108}$ These measures also encourage building owners to request local AICs for an efficiency evaluation. ${ }^{109}$ As opposed to most local regulations, these measures institute criminal penalties for certain behavior from construction department employees including negligence, abuse of power, and fraud. ${ }^{110}$ As shown above, Chongqing has enacted various regulations that promote the economy as well as protect the environment and society. Chengdu, which is Chongqing's main competitor in Western China, has done the same.

\section{Sichuan Province and Chengdu City}

${ }^{90} I d$. art. 5.

${ }^{91}$ See generally id.

${ }^{92}$ Id. art. 6.

${ }^{93}$ Id. art. 9.

${ }^{94}$ Id. art. 17.

${ }^{95}$ See id.

${ }^{96}$ Id. art. 56.

${ }^{97}$ Id. art. 25.

${ }^{98}$ Id. art. 26.

${ }^{99}$ Id. art. 37.

${ }^{100}$ Id. art. 46.

101 See, e.g., James Fallows, 'Gingko Fever in Chongqing': The Billion-Dollar Trees of Central China, The ATLAnTic (May 13, 2011), http://www.theatlantic.com/international/archive/2011/05/gingko-fever-in-chongqing-the-billion-dollar-trees-of-central-china/238885/ (reporting that Chongqing unearthed a substantial portion of its urban trees in order to make room for trees preferred by a famous local figure).

102 See Chongqingshi Jianzhu Jieneng Tiaoli (重庆市建筑节能条例) [Measures of Chongqing Municipality on Energy-Saving Buildings] (promulgated by the Chongqing Municipal People's Congress, Nov. 23, 2007, effective Jan. 1, 2008).

${ }^{103} I$ d. art. 2.

${ }^{104}$ See id. art. 3.

${ }^{105}$ See id. art. 13.

${ }^{106} I d$.

${ }^{107}$ See id. art. 22.

${ }^{108} I d$. art. 23.

109 Id. art. 27.

${ }^{110}$ See id. art. 34. 
Chengdu is the other rapidly developing city in Western China. Unlike Chongqing, which wields both provincial and municipal powers, Sichuan exercises provincial power over Chengdu. The Chongqing regulations discussed above originate from the same legislative body. In comparison, Chengdu's local government and AICs must follow the laws passed by both the Sichuan Provincial People's Congress and the Chengdu Municipal People's Congress.

\section{a. Sichuan Province}

\section{i. Promotion and Regulation of Economy}

Sichuan has passed a variety of regulations in order to regulate and promote its economy. One of the regulations that focuses on foreign investment is the Measures of Sichuan Province on the Protection of Investment Rights of Overseas Chinese Citizens (2011 Revision). ${ }^{111}$ These measures seek to promote investment from Chinese living outside of the PRC by providing incentives and additional protections. ${ }^{112}$ Overseas Chinese investors, their spouses, their children, and their employees who are also Chinese citizens from abroad are treated as Sichuan citizens. ${ }^{113}$ Related departments also provide them with convenient procedures for applying for residency. ${ }^{114}$ Additionally, companies started by overseas Chinese receive preferential treatment. ${ }^{115}$

These measures allow Chinese citizens that are overseas to start a company with a patent, scientific research or proprietary technology. ${ }^{116}$ Furthermore, these companies can take advantage of any policies implemented to attract Chinese citizens that have studied abroad. ${ }^{117}$ These measures also provide tax exemptions to these companies if they either incorporate new and advanced technology or are part of an encouraged industry. ${ }^{118}$ One of the primary concerns of many foreign companies participating in the PRC is whether they will be able to transfer their profits outside of the country. Chinese from abroad and their employees do not face this problem in Sichuan because these measures specifically state that they may remit their profits. ${ }^{119}$ Additionally, these measures provide various rights to companies started by overseas Chinese. For example, these companies have the right to deny the police access to their premises if the police do not present required paperwork. ${ }^{120}$ Overall, these measures grant substantial incentives to overseas Chinese. In addition to measures that promote investment from overseas Chinese, Sichuan has also enacted several regulations pertaining to the technology market.

The primary technology market regulations are contained in the Measures of Sichuan Province on the Technology Market (2009 Amendment). ${ }^{121}$ These measures promote the development of the economy by improving technology transfers. ${ }^{122}$ They apply to patent licensing, consulting, technology-related stocks, etc. ${ }^{123}$ They also list the prohibited activities associated with technology transfers: infringing the IP rights or technical interests of other parties, providing false information, collusive tendering, causing a party to enter into an agreement through fraud or coercion, harming national or public interests, and other behavior prohibited by the law. ${ }^{124}$

A second set of regulations on technology is the Measures of Sichuan Province on the Popularization of Science and Technology (2012 Revision). ${ }^{125}$ The purpose of these measures is to increase economic development through

\footnotetext{
${ }^{111}$ See Sichuansheng Huaqiao Touzi Quanyi Baohu Tiaoli (2011 Xiuding) (四川省华侨投资权益保护条例(2011 修订)) [Measures of Sichuan Province on the Protection of Investment Rights of Overseas Chinese Citizens (2011 Revision)] (promulgated by the Sichuan Provincial People's Congress, Nov. 25, 2011, effective Nov. 25, 2011).

${ }^{112}$ See id. art. 1.

113 Id. art. 9.

${ }^{114} I d$.

${ }^{115}$ See id. art. 14.

${ }^{116} \mathrm{Id}$.

${ }^{117}$ See id.

${ }^{118}$ See id.

119 Id. art. 19.

${ }^{120}$ See id. art. 21

121 See Sichuansheng Jishu Shichang Tiaoli (2009 Xiuzheng) (四川省技术市场条例(2009 修正)) [Measures of Sichuan Province on the Technology Market (2009 Amendment)] (promulgated by the Sichuan Provincial People's Congress, Mar. 27, 2009, effective Mar. 27, 2009).

${ }^{122}$ See id. art. 1.

123 Id. art. 3.

${ }^{124}$ See id. art. 9.

${ }^{125}$ See Sichuansheng Kexue Jishu Puji Tiaoli (2012 Xiuding) (四川省科学技术普及条例(2012 修订)) [Measures of Sichuan Province on the Popularization of Science and Technology (2012 Revision)] (promulgated by the Sichuan Provincial People's Congress, Sept. 21, 2012, effective Nov. 1, 2012).
} 
educating the public on science and technology. ${ }^{126}$ They apply to activities involving science and technology that the public can understand, accept, and utilize. ${ }^{127}$ Municipal and county-level governments must reserve a portion of their budget for public education on science and technology. ${ }^{128}$ Methods of education include formal education, cultural education, advertisements, and news. ${ }^{129}$

Sichuan must conduct science-related activities every March, and these activities should focus on bringing rural-oriented science to the countryside. ${ }^{130}$ Also, the first three weeks of every May are called Science and Technology Weeks. ${ }^{131}$ During this time period, the local government must conduct community-oriented activities involving science and technology. ${ }^{132}$ A portion of every school's education should be dedicated to science and technology. ${ }^{133}$ As such, schools must dedicate a certain number of credits to science and technology, participate in competitions, conduct lectures, and organize field trips. ${ }^{134}$ These measures also place other various responsibilities on local governments such as that they must help fund the gradual improvement of science and technology. ${ }^{135}$ In addition to regulations that promote and regulate the local economy, Sichuan has also implemented measures in order to protect the environment.

\section{ii. Protections for Society and the Environment}

Sichuan contains 80 million inhabitants and is roughly the size of France. ${ }^{136}$ It is much larger than Chongqing which has approximately 33 million people. ${ }^{137}$ Sichuan also has more forest preserves. In order to protect its nature preserves, the Sichuan Provincial People's Congress passed the Measures of Sichuan Province on the Administration of the Protection of Nature Preserves (2009 Amendment). ${ }^{138}$ These measures provide detailed regulations that promote the protection and administration of nature preserves, the protection of Sichuan's nature, and the continued existence of Sichuan's plant and animal species. ${ }^{139}$ They begin by stating that county-level governments have the primary duty to protect their natural resources. ${ }^{140}$ They also suggest that local governments above the county-level should consider the relationship between the protection of the enviroonment and the development of Sichuan's economy. ${ }^{141}$ Nature preserves should be established according to national law, the presence of rare species, the location of water conservation areas, geographical features, and other areas requiring special protection. ${ }^{142}$

These measures are particularly effective because they establish the duties for specific departments. ${ }^{143}$ Although county-level governments must protect their nature preserves, specific provincial departments also have duties related to these areas. ${ }^{144}$ The forestry department is generally in charge of forests and wildlife. ${ }^{145}$ The agricultural department takes care of animal species related to agriculture, the construction department maintains nature preserves, the geology and mineral departments address issues related to geology and minerals, the livestock

\footnotetext{
${ }^{126}$ See id. art. 1.

127 Id. art. 2.

${ }^{128}$ Id. art. 7.

${ }^{129}$ See id. art. 9.

${ }^{130}$ Id. art. 17.

${ }^{131}$ Id.

${ }^{132} I d$.

${ }^{133}$ Id. art. 21.

${ }^{134}$ Id.

${ }^{135}$ See id. art. 32.

${ }^{136}$ See China: Sichuan, City Population DE (July 30, 2011), http://www.citypopulation.de/China-Sichuan.html; see also Sichuan Province, SOCIETY FOR ANGLO-CHINESE UNDERSTANDING, http://www.sacu.org/sichuan.htm (last visited Apr. 17, 2013).

137 See China: Chongqing, City PopUlation DE (July 30, 2011), http://www.citypopulation.de/China-Chongqing.html.

${ }^{138}$ See Sichuansheng Ziran Baohuqu Guanli Tiaoli (2009 Xiuzheng) (四川省自然保护区管理条例(2009 修正)) [Measures of Sichuan Province on the Administration of the Protection of Nature Preserves (2009 Amendment)] (promulgated by the Sichuan Provincial People's Congress, Mar. 27, 2009, effective Mar. 27, 2009).

139 See id. art. 1.

${ }^{140}$ See id. art. 2.

${ }^{141}$ Id. art. 5.

${ }^{142}$ Id. art. 8.

${ }^{143}$ See id. art. 15.

${ }^{144}$ See id.

${ }^{145} \mathrm{Id}$.
} 
department administers grassland reserves, and the water conservancy department looks after water ecosystems and aquatic wildlife. ${ }^{146}$ The departments' respective local governments provide the necessary funding. ${ }^{147}$

These measures also establish fines associated with nature preserves. Specifically, any employee of the departments listed above that fails to perform his or her duties may receive a fine from 1000 RMB (app. 161 USD) to 3000 RMB (app. 482 USD). ${ }^{148}$ In addition to remedying the situation, a more severe fine of 10,000 RMB (app. 1,607 USD) to 50,000 RMB (app. 8,037 USD) is imposed on any employee who either pollutes a nature reserve or otherwise causes damage. ${ }^{149}$ However, these protections only apply to official nature preserves.

The Sichuan Provincial People's Congress also passed the Measures of Sichuan Province on the Protection of Natural Forests (2009 Amendment) in order to protect forests that are not part of a nature preserve. ${ }^{150}$ Local governments should consider how the protection of forests relates to social and economic growth. ${ }^{151}$ Also, the harvesting of the following types of forest is prohibited: any area of 100 hectares of virgin forest, ${ }^{152}$ any amount of virgin forest that is part of the local government's natural forest protection plan, forests along Yangtze River, the Yellow River, and their reservoirs, forests in mountain zones that have suffered multiple natural disasters, and other forests specifically banned by the provincial government. ${ }^{153}$ These measures also prohibit the commercial logging of natural forests and the destruction of natural forests through land cultivation, quarrying, mining, etc. ${ }^{154}$ Loggers must obtain licenses before they begin work. ${ }^{155}$ Finally, these measures place various fines on activity related to the deforestation of natural forests. For example, a violation of these regulations will result in a combination of 1) compensating the local government in money damages, 2) confiscation of the trees, 3) replanting ten times the number of trees removed, and 4) additional fees calculated by five to ten times the value of the felled trees. ${ }^{156}$ Sichuan also has measures that protect natural resources other than nature preserves and forests.

Sichuan has enacted a regulation called the Measures of Sichuan Province on the Protection of Wetlands. ${ }^{157}$ These measures follow the basic form of the other two regulations on the protection of the environment. The following factors establish whether an area qualifies as a wetland nature preserve: whether the area is on Sichuan's list of important wetlands, whether the area is representative of a wetland, the diversity and the amount of rare and endangered species, whether birds use the area as a breeding ground or as a migratory stopover, the extent that animals use the area, and other factors such as ecological, cultural or scientific value. ${ }^{158}$ Several other activities are also prohibited such as destroying a wetland, dumping chemicals, mining, collecting bird eggs, fishing, and introducing foreign species. ${ }^{159}$ These measures also list the fines for engaging in prohibited activities. ${ }^{160}$ These three measures have a different focus than the Chongqing measures for the protection of the environment and society because Sichuan has more natural resources and a much larger area of land covered by forests. However, although the focus of legislation varies between Sichuan and Chongqing, the regulations passed by Chengdu are relatively similar to Chongqing's regulations.

\section{b. Chengdu City}

\section{i. Promotion and Regulation of Economy}

Some of Chengdu's regulations are extremely similar to their Chongqing counterparts. For example, both cities have enacted a regulation on the recognition and protection of local trademarks. The Measures of Chengdu

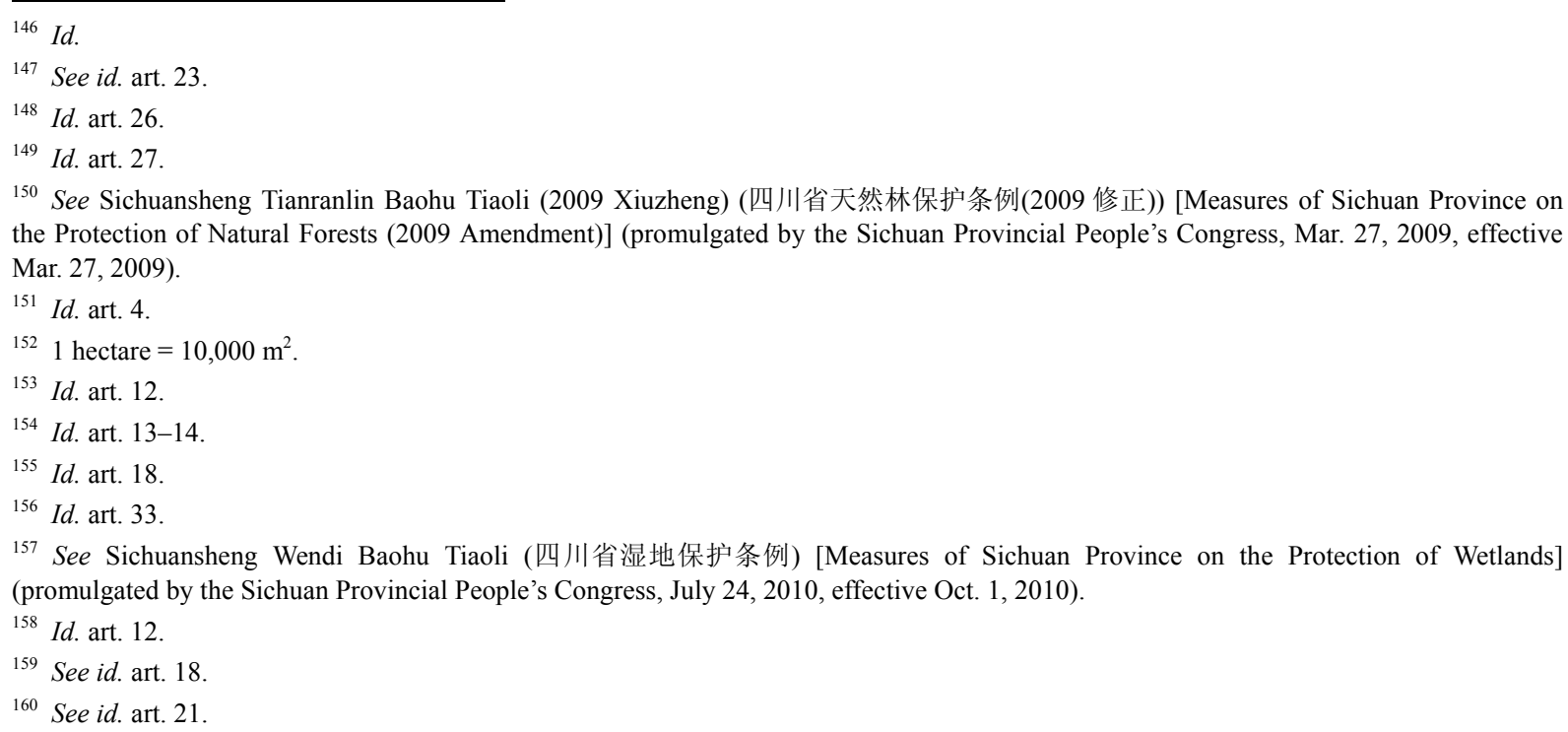


Municipality on Famous Trademark Recognition and Protection (2011 Revision) are very similar to the Measures of Chongqing Municipality on Famous Trademark Recognition and Protection that are mentioned above. ${ }^{161}$

A regulation that promotes the economy and is also different from the Chongqing regulations discussed above is the Measures of Chengdu Municipality on the Promotion of Employment. ${ }^{162}$ The Chengdu Municipal People's Congress enacted these measures in January, 2013, in order to promote the economy through the advancement and regulation of employment. ${ }^{163}$ Municipal and county-level governments must place employment has a top priority when considering how to promote the local economy. ${ }^{164}$ The municipal government must also implement a system that monitors who is employed and who has filed for unemployment benefits. ${ }^{165}$ Furthermore, the municipal government must support training programs established by local enterprises. ${ }^{166}$

These measures also state that municipal and county-level governments shall create entrepreneurial parks and business creation centers which provide training and other services to workers. ${ }^{167}$ Additionally, the municipal government must provide unemployment insurance which supports unemployed people and helps them find employment. ${ }^{168}$ The funds for unemployment insurance come from the local governments. ${ }^{169}$ These measures also institute fines for violations such as using fraud to secure unemployment benefits. ${ }^{170}$ On the same day it enacted these measures, the Chengdu Municipal People's Congress also passed another regulation on employment.

The Measures of Chengdu Municipality on the Promotion of Vocational Education are the only local regulation in the PRC that separately promotes vocational training. ${ }^{171}$ The purpose of these measures is to promote the local economy by providing qualified students and employees with vocational training. ${ }^{172}$ The municipal and county-level governments shall organize joint meetings that convene to discuss related issues. ${ }^{173}$ The municipal government must include vocational training in its annual budget, ${ }^{174}$ and funds are distributed to students in municipal vocational colleges and secondary municipal vocational institutes. ${ }^{175}$ These measures also state that the amount of funds in the city's budget must meet or exceed national funding standards. ${ }^{176}$ Additionally, all of the schools that wish to establish secondary vocational programs must apply to relevant local departments. ${ }^{177}$

Local corporations should also participate in the vocational education of students. ${ }^{178}$ They are directed to educate students about their business and the skills valued in their industry, create a training model for the students, establish an internship program, and help graduates pursue employment. ${ }^{179}$ Schools that arrange internships must sign an agreement with these companies and require students to purchase life insurance. ${ }^{180}$ Also, interns are to be

\footnotetext{
${ }^{161}$ Compare Measures of Chongqing Municipality on Famous Trademark Recognition and Protection, supra note 80, with Chengdushi Zhuming Shangbiao Rending he Baohu Guiding (2011 Xiuding) (成都市著名商标认定和保护规定(2011 修订)) [Measures of Chengdu Municipality on Famous Trademark Recognition and Protection (2011 Revision)] (promulgated by the Chengdu Municipal People's Congress, Sept. 29, 2011, effective Jan. 1, 2012).

162 See Chengdushi Jiuye Cujin Tiaoli (成都市就业促进条例) [Measures of Chengdu Municipality on the Promotion of Employment] (promulgated by the Chengdu Municipal People's Congress, July 6, 2012, effective Jan. 1, 2013).

${ }^{163}$ See id. art. 1.

${ }^{164}$ Id. art. 4.

${ }^{165} \mathrm{Id}$. art. 17.

${ }^{166} I d$. art. 22.

${ }^{167}$ Id. art. 35.

168 Id. art. 45.

169 Id. art. 46.

${ }^{170}$ See id. art. 55.

${ }^{171}$ See Search Results From Query on Term “职业教育促进'(Promotion of Vocational Education) under 地方法规规章 (Local Legislation), PKULAW.CN (last visited Mar. 5, 2013) (providing that the only local legislation that includes the phrase “职业教育促进” is the Measures of Chengdu Municipality on the Promotion of Vocational Education.

${ }^{172}$ See id. art. 1.

${ }^{173}$ Id. art. 8.

${ }^{174}$ Id. art. 11

${ }^{175} \mathrm{Id}$.

${ }^{176} I d$.

${ }^{177}$ Id. art. 19.

${ }^{178}$ Id. art. 31.

${ }^{179}$ Id. art. 32.

${ }^{180}$ Id. art. 33.
} 
given an appropriate amount of compensation for their work. ${ }^{181}$ Finally, these measures prohibit specific types of internships that involve danger such as ones related to radiation and explosives, a likelihood of illegal behavior such as work in nightclubs and bath centers or work that is completely unrelated to a student's education. ${ }^{182}$ In addition to its regulations that promote the local economy, Chengdu has also enacted regulations to protect society and the environment.

ii. Protections for Society and the Environment

The Measures of Chengdu Municipality on the Supervision of Product Quality (2012 Amendment) maintain product quality through the regulation of manufacturing and sales. ${ }^{183}$ Municipal and county-level governments should consider how to balance product quality with the development of the local economy. ${ }^{184}$ These measures ban the production and sale of certain products such as those that are obsolete, counterfeit, adulterated, impure or have failed testing. ${ }^{185}$ To this end, Chengdu will maintain a quality control department. ${ }^{186}$ Additionally, these measures provide fines for specific violations. ${ }^{187}$

Chengdu has also passed regulations to address issues related to the city's sanitation. The Chengdu Municipal People's Congress passed the Measures of Chengdu Municipality on the Administration of Appearance and Environmental Sanitation (2012 Amendment) which apply to all of the areas of Chengdu including outlying towns. ${ }^{188}$ The owner or supervisor of an area has the duty to maintain a clean and healthy environment. ${ }^{189}$ These measures also place various restrictions on government departments and private citizens. ${ }^{190}$ For example, related municipal departments must consider the effects of public lighting during night-time hours. ${ }^{191}$ Finally, these measures state the fines associated with harming the city's environment. ${ }^{192}$

The final local regulation discussed in this article is the Measures of Chengdu Municipality on the Protection of Surrounding Ecological Areas. ${ }^{193}$ These measures determine the amount of municipal land that shall be dedicated to agriculture and gardening. ${ }^{194}$ Surprisingly, these measures are so specific that they determine the exact amount of square meters in each district. ${ }^{195}$ They also state that the total area of any supporting buildings cannot exceed half of a square kilometer. ${ }^{196}$ These measures became effective in January, 2013. ${ }^{197}$ It is likely that the Chengdu Municipal People's Congress passed them in response to the city's rapid growth. These measures are a prime example that the municipal and provincial governments of western cities like Chongqing and Chengdu are enacting legislation to combat the adverse effects of rapid economic expansion.

\subsubsection{Economic Effects of Westward Expansion}

(1). Western China

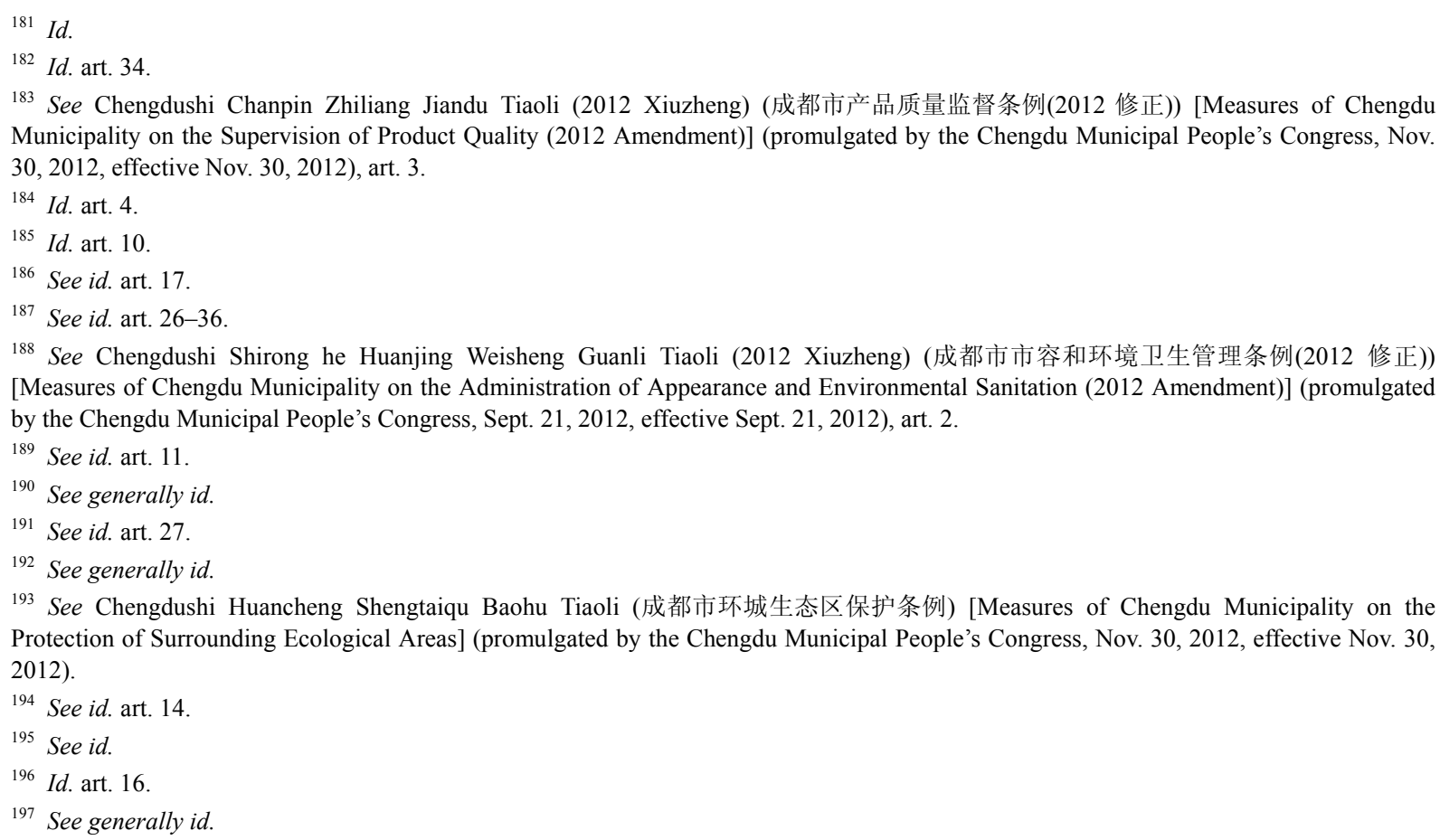


Western China is experiencing a rapid development of its suburban centers due to economic forces, national legislation, and local regulations. Chengdu has proven to be an important center in Western China. ${ }^{198}$ To put Chengdu's development in perspective, its annual GDP growth in 2011 was 15.2 percent while Beijing experienced an 8.1 percent growth. ${ }^{199}$ Chengdu has also been chosen as the site for the 2013 Fortune Global Forum. ${ }^{200}$ Chengdu's rapid growth is partially due to its relaxed tax regulations and other economic policies. ${ }^{201}$ On a larger scale, the total value of imports and exports in Western China was 9.4 times greater in 2011 than in 1999. ${ }^{202}$ Remarkably, FDI into Western China increased ten times during the same period. ${ }^{203}$

The development of Kunming's infrastructure is a key example of the speed and scale of Western China's expansion. Kunming is currently installing multiple subway lines throughout the city. ${ }^{204}$ The constant hum of construction, never-ending detours, and billows of smoke emitting from construction points will pervade the city for several years as it enacts its original plan for six subway lines and expects an additional eight lines. ${ }^{205}$ Kunming has already completed the first stage of one of its subway lines, and projects that the subway system will serve 3.7 million passengers per day. ${ }^{206}$ The subway system will also connect Kunming to its new international airport. ${ }^{207}$

Kunming Changshui International Airport cost 23 billion RMB (app. 3.6 billion USD) and will serve 65 million passengers a year. ${ }^{208}$ This airport has the second largest terminal building in the PRC, houses 98 companies including banks and post offices, and contains 40 lounges. ${ }^{209}$ The amount of investment in Kunming's new airport is immense when considering that Kunming is not one of Western China's largest cities. It also exemplifies Kunming's confidence that the local economy will rapidly develop as domestic and foreign companies invest in Western China.

Expansion in Western China is also affecting where people live and work. Workers are migrating into large western cities as production sites gradually move inland. ${ }^{210}$ Specifically, workers are expected to continue to move into the developing provinces such as Wuhan and into emerging megacities including Kunming and Xi'an. ${ }^{211}$ Chengdu may be the best example of this western urban migration due to the massive influx of migrant workers into the city. ${ }^{212}$ There are three factors that contribute to the number and ratio of migrant workers in Chengdu. Firstly, immigration into Chengdu is higher than emigration out of Chengdu. ${ }^{213}$ Many of the immigrants are originally from Sichuan, moved to Eastern China in search of work, and are now returning to Chengdu. ${ }^{214}$ Secondly, Chengdu's urban area takes in more of the migrants than the surrounding areas. ${ }^{215}$ Lastly, the number of

198 See, e.g., Yanrong Zhao, Chengdu Makes Inroads as Key Transportation Center, ChINA DAILY (Feb. 22, 2013), http://www.chinadaily.com.cn/business/2013-02/22/content_16247856.htm.

199 Western China, New Powerhouse for China's Economy, CHINA Briefing (Mar. 5, 2013), http://www.china-briefing.com/news/2013/03/05/western-china-new-powerhouse-for-chinas-economy.html.

${ }^{200} I d$.

201 See Chen Jia, Chengdu Leading Light of Development in Western China, ChinA DAILY (Feb. 8, 2013), http://www.chinadaily.com.cn/business/2013-02/08/content_16215723.htm.

202 Western China, New Powerhouse for China's Economy, supra note 199.

${ }^{203} I d$.

204 See Kunming Approves Eight New Subway Lines, Go KunMING,

http://www.gokunming.com/en/blog/item/2835/kunming_approves_eight_new_subway_lines (last visited Mar. 17, 2013).

${ }^{205}$ See id.

206 Kunming Rail Transit (KRT) / Kunming Metro, China, RAILWAY-TECHNOLOGY.COM, http://www.railway-technology.com/projects/kunming-rail-transit-krt-kunming-metro/ (last visited Mar. 7, 2013).

207 Id.

208 New Kunming Airport Open for Business, ChinA DAILY (June 28, 2012), http://www.chinadaily.com.cn/china/2012-06/28/content_15532206.htm.

209 Kunming Changshii International Airport, TRAVELCHINAGuide.COM, http://www.travelchinaguide.com/cityguides/yunnan/kunming/airport.htm (last visited Mar. 17, 2013).

${ }^{210}$ See Bettina Gransow, Internal Migration in China - Opportunity or Trap?, Focus MigRATION (Dec. 2012), pg. 3, available at http://www.google.com.hk/url?sa=t\&rct=j\&q=Internal+Migration+in+China+\%E2\%80\%93+Opportunity+or+Trap $\% 3 \mathrm{~F} \&$ source=web\&cd=1 \&ved $=0$ CDkQFjAA\&url=http $\% 3 \mathrm{~A} \% 2 \mathrm{~F} \% 2 \mathrm{Fwww} . b p b . d e \% 2 \mathrm{Fsystem} \% 2 \mathrm{Ffiles} \% 2 \mathrm{Fdokument}$ pdf $\% 2 \mathrm{FPB}$ Internal\%2520Migration $\% 2520$ in \%2520China_2012_0.pdf\&ei=B3w3UdrFJ8qqywGv4YDIBw\&usg=AFQjCNH1UxfiVrARGJqcQYjIq4ByZAb27Q.

211 See id. at pg. 5.

${ }^{212}$ See Yujian Wang, Urban Development and Urban Planning in Contemporary China - A Case Study of Chengdu, MONTANA ST. U. (May 2012), pg. 4., available at http://etd.lib.montana.edu/etd/2012/wang/WangY0812.pdf.

${ }^{213} \mathrm{Id}$. at pg. 55.

${ }^{214}$ See id. at pg. 56.

${ }^{215} I d$. at pg. 55. 
Chengdu's immigrants is higher than the number of births in the city. ${ }^{216}$ Migrant workers will continue to come to Western China as it continues to undergo rapid expansion.

\section{(2). Eastern China}

Eastern China is already experiencing the effects of rising labor and land costs. The migration of domestic and foreign companies substantially affects Eastern China's economy. The PRC has over 250 million migrant workers and, as their home provinces begin to offer them work opportunities, many of them return home. ${ }^{217}$ This has led to serious labor shortages in Eastern China. ${ }^{218}$ Cities throughout Western China are contributing to this Eastern labor shortage through job fairs geared towards convincing migrant workers to return home. ${ }^{219}$ There are currently over 58 million children in Western China whose parents are working in Eastern China. ${ }^{220}$ Those parents are only working in Eastern China because they could not find work in their own provinces. When work becomes available in Western China, these parents will return home in massive numbers in order to live and work near their children.

Labor shortages in Eastern China will become increasingly exacerbated due to the One Child Policy. ${ }^{221}$ Although wages will continue to rise throughout the PRC, its labor force will gradually shrink. ${ }^{222}$ Furthermore, it is unlikely that the removal of the One Child Policy will alleviate this labor shortage because the One Child Policy has changed fertility preferences in the PRC. ${ }^{223}$ To put this labor shortage in perspective, the number of migrant workers in Eastern China is decreasing around eight to nine percent per year. ${ }^{24}$ In comparison, the number of migrant workers in Western China increased 33.2 percent from 2008 to $2009 .^{225}$ Eastern China will experience increasingly drastic labor shortages as migrant workers return home.

Eastern China is also experiencing several massive real estate problems. In addition to the exorbitant housing costs in Beijing and Shanghai, Eastern China is home to most of the world's distressed malls. The New South China Mall is the world's largest mall. ${ }^{226}$ It has 7.1 million square feet of leasable area and has space for 2,350 stores. ${ }^{227}$ The world's largest mall also has a 99.5 percent vacancy rate. ${ }^{228}$ Like most of the PRC's "ghost malls," New South China Mall has been vacant since its completion. ${ }^{229}$

The PRC's ghost malls are a result of poor planning and overconfidence in the consumer market. ${ }^{230}$ These malls are part of a larger real estate problem. The PRC simply has too much commercial and living space. ${ }^{231}$ A country with the PRC's level of GDP per person should have around 20 square meters of living area per person. ${ }^{232}$ The PRC has over 30 square meters per person. ${ }^{233}$ Additionally, the PRC continues to pump out residential property. In February 2012, an astounding 2.98 billion square meters of residential property was under construction. ${ }^{234}$

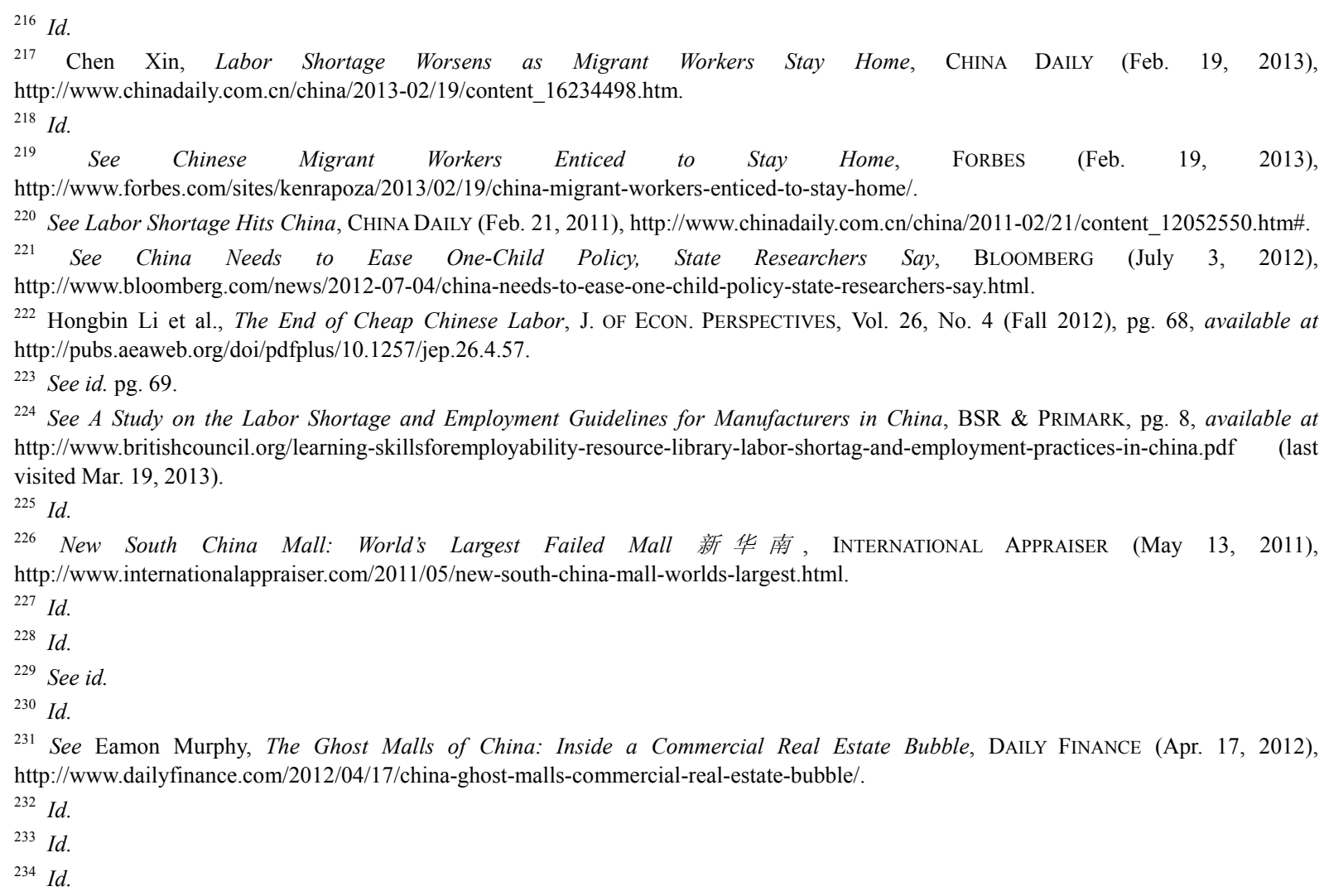


Commercial property leased as office space is also suffering from high vacancy rates. For example, the vacancy rate in prime office buildings in Guangzhou City is approximately 20.4 percent. ${ }^{235}$ Eastern China is on the precipice of a residential and commercial real estate bubble. ${ }^{236}$

\section{Analysis}

Part A of this section analyzes the local regulations discussed above; Part B evaluates the current situation in Eastern China; Part C considers the future of Western China.

\subsection{Analysis of Local Regulations}

The local regulations discussed above provide an opportunity to understand the policy considerations that influence local legislation in Western China. The most important policy consideration is economic development. The Measures of Chongqing Municipality on the Promotion of Development are a primary example of general measures that promote the local economy. These measures are very broad and discuss various topics related to the economy. The Chongqing Municipal People's Congress clearly knew that the measures would not be effective by themselves and, therefore, passed additional legislation on specific issues that are addressed in these general measures. This shows the emphasis that Chongqing places on economic development.

Chongqing's local regulations also demonstrate that it highly values FDI and local businesses. Chongqing has the opportunity to attract a massive amount of FDI because many foreign companies are moving to Western China and because Chongqing and Chengdu are the two main investment destinations. Chongqing determined that local governments must permit and promote FDI. However, the Chongqing legislature is also concerned that foreign businesses will negatively affect local SMEs. This policy consideration led to the Measures of Chongqing Municipality on the Promotion of Small and Medium Enterprises. These measures protect SMEs from the effects of FDI through tax breaks and free or subsidized land. The Measures of Chongqing Municipality on Famous Trademark Recognition and Protection are also an effective tool for the promotion of local businesses. These measures promote the protection and development of successful local goods. Additionally, local governments including Chongqing will provide monetary incentives for local well-known trademark registration. This proves to be a strong incentive for local companies to develop their brands.

Sichuan and Chengdu also consider the local economy, FDI, and local businesses throughout their regulations. Sichuan distinguishes itself from Chongqing through the Measures of Sichuan Province on the Protection of Investment Rights of Overseas Chinese Citizens (2011 Revision). Although Chongqing's regulations explicitly welcome Chinese citizens with experience abroad, in practical terms they do not function to attract overseas Chinese because they do not offer substantial incentives. The Sichuan regulations attempt to distinguish Sichuan from other western regions by offering substantial incentives in order to establish Sichuan as the center for FDI originating from overseas Chinese.

The Measures of Chengdu Municipality on the Promotion of Employment distinguish Chengdu by further educating its local population and attracting workers into Chengdu. Additionally, Chengdu reinforces local education through the Measures of Chengdu Municipality on the Promotion of Vocational Education. Chongqing, Sichuan, and Chengdu have carefully drafted legislation in order to promote their local economies. Specifically, their regulations focus on FDI and local businesses. Surprisingly, the promotion of the local economy spills over into regulations for the protection of society and the environment. Most of the regulations that protect the environment also state that their purpose is to promote the economy. Furthermore, these regulations remind local governments to consider how the protection of the environment affects economic development.

Chongqing does not have general measures that protect society or the environment. Instead, Chongqing has enacted regulations that address specific environmental issues such as the protection of forests. Although the Measures of Chongqing Municipality on the Promotion of Forest Expansion provide some incentives for expanding Chongqing's forests, they do not promote forest expansion to the extent that other regulations promote the local economy. These measures essentially state that the local population should protect forests and then list illegal activities associated with the destruction of forests. It is also highly unlikely that local governments will comply with the percentage requirements for land covered by forest because the regulations do not provide mechanisms for the implementation or supervision of these requirements.

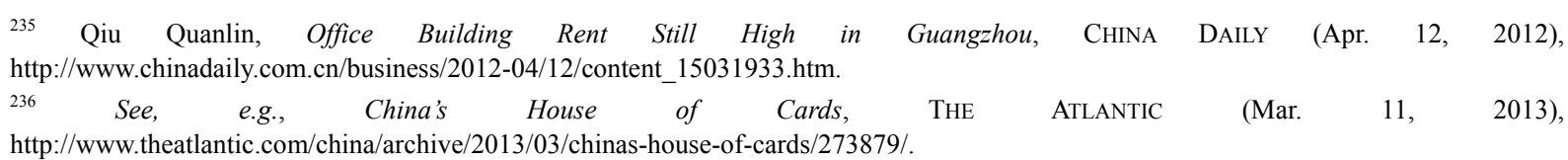


Sichuan's regulations for the protection of the environment are similarly limited. Although Sichuan has more regulations related to the environment than Chongqing, it also fails to provide substantial incentives for the development and protection of the environment. Rather, its regulations establish an outline for the maintenance of the environment and list related illegal activities. Although the Measures of Sichuan Province on the Administration of the Protection of Nature Preserves (2009 Amendment) are also limited, their detailed list of specific responsibilities per department is commendable. Also, Chengdu provides a surprising requirement in the Measures of Chengdu Municipality on the Protection of Surrounding Ecological Areas. These measures state the exact amount of land dedicated to agriculture and gardening. It is possible that Chengdu could enforce this regulation by assessing the extent that each district has reserved land for agriculture and gardening. However, the regulations currently serve as a suggestion to Chengdu's districts and, unless Chengdu rigorously enforces this requirement, it is impossible to determine the extent that its districts dedicate land to agriculture and gardening.

The local governments discussed above have done an outstanding job in enacting regulations that promote their local economies. Their regulations show a deep understanding of the extent that they want to promote the economy, the responsibilities of each department, and the obstacles that they face. Additionally, their regulations consider the relationship between FDI and the local economy. They serve to both invite FDI and migrant workers while simultaneously protecting local SMEs. The Measures of Sichuan Province on the Protection of Investment Rights of Overseas Chinese Citizens (2011 Revision) even show a large amount of creativity which is seldom seen in local regulations. Overall, it is likely that these local regulations will effectively promote and regulate these local economies.

In comparison, these local governments have not enacted meaningful legislation for the protection of the environment. The first red flag that the environment is not a high priority is that these regulations state that their purpose is to promote the economy and that local governments should consider how protecting the environment affects economic development. Also, these regulations do not contain a modicum of creativity. Rather, they are limited to assigning the responsibilities of local departments and listing illegal activities. Although they sometimes provide minimal incentives for the expansion and protection of the environment, their incentives are not adequate as to invite any real investment. The local governments understand that the protection of the environment should be a priority. However, they are more concerned with developing their local economy.

\subsection{Current Situation in Eastern China}

Eastern China is in the midst of transitioning away from being the manufacturing hub of the PRC. It contains all of the developed areas in the PRC such as Beijing, Shanghai, Shenzhen, and Guangzhou. Its labor and land prices will also become progressively more expensive and, accordingly, foreign manufacturing will slowly leave Eastern China for less expensive alternatives. However, the gradual decrease in manufacturing does not mean that Eastern China will cease to develop. Rather, Eastern China has the opportunity to foster its service industry and develop world-class cities. Beijing will remain the political hub of the PRC and Shanghai will maintain its status as the business and financial center. Shenzhen and Guangzhou will also continue to develop due to their proximity to Hong Kong.

Local regulations in Eastern China actually detract from its attractiveness for foreign manufacturers. Local governments no longer provide incentives to foreign companies. Unfortunately, foreign companies are also deterred from Eastern China because of the local promotion of workers' rights and employment contracts. Nonetheless, the development of local regulations in Eastern China shows a more advanced stage of social development than in Western China. Although these local regulations increase the cost of doing business, they also foster a more stable society. This is attractive to foreign companies and, as its service industries grow, Eastern China will experience a positive reaction from foreign companies.

Perhaps the most pressing issue that faces Eastern China is real estate. As discussed above, the real estate bubble in Eastern China extends to both residential and commercial property. Real estate developers should not construct large amounts of residential and commercial property in areas that have already proven that they cannot support growth. The consequences of this practice are empty cities, ghost malls, and vacant office buildings. On the other hand, real estate in Beijing and Shanghai is incredibly expensive. This has led to unfair practices such as purchasing condos under a false hukou ${ }^{237}$ and then reselling them at higher prices. Despite the high housing prices in major cities, local price controls are beginning to stabilize the market. Also, local governments are becoming increasingly diligent in monitoring deceptive hukou use. Eastern China will experience complicated societal issues

\footnotetext{
237 "Hukou” (户口) is used by both Chinese and foreigners to refer to the PRC's residency system. Each citizen of the PRC is assigned a hukou and, depending on the local regulations, will only be allowed to acquire a certain number of residences depending on whether the person has a hukou from that area.
} 
as it transitions from a developing to developed society. However, the changes in Eastern China will pale in comparison to the economic, societal, and environmental effects of development on Western China.

\subsection{Future for Western China}

\subsubsection{Economy}

Western China will undergo considerable transformation as it experiences rapid development. Kunming is a primary example of the effects of this development. In five years, Kunming will have a state of the art subway system, its airport will be one of the largest hubs to Southeast Asia, and it will begin developing its own service sector. Kunming is not even one of Western China's largest cities. Chongqing and Chengdu are likely to become modern metropolises that compare to Beijing and Shanghai.

Foreign companies will participate in Western China in the same manner that they are currently in Eastern China. Manufacturing will be the first step. Many foreign companies will choose Western China as their manufacturing location because it is less expensive than Eastern China and also has more reliable energy and a more highly educated workforce than developing countries in Southeast Asia. Foreigners will also funnel FDI into joint ventures (hereinafter "JVs") and WFOEs. Unlike Eastern China, foreigners are likely to prefer WFOEs over JVs because of Western China's relaxed regulations on WFOEs. This will allow foreigners more control and certainty over their business interests.

Multinational companies will also increase their sales efforts in Western China as its middle class gradually has more money to spend on consumer products. Western China already has an infrastructure that permits market transparency. Foreigners can perform their own market research and determine which areas are likely to purchase certain types of products. For example, foreign car companies opened stores in Kunming because they were aware that many wealthy Chinese retire and move to Kunming. Stores such as Wal-Mart focus on larger markets such as Chongqing and Chengdu. The final step for foreign companies will be to set up offices in Western China. Many of the Fortune 500 companies have already opened offices in Chengdu. Smaller foreign companies will also open offices in Western China.

\subsubsection{Society}

The rapid development in Western China will have both positive and negative effects. Perhaps the most important positive effect is that there will be an increased per capita income. Residents of developing cities in Western China will have more business opportunities and better jobs. People living in the same province or in other provinces will also move to large cities because of these opportunities. Development will also likely lower unemployment rates, reduce the number of impoverished people, and reduce infant mortality.

Western China's development will foster education as local governments have more funding and companies require progressively more skilled employees and workers. This will also foster advancements in technology. Another positive effect of development is the awareness of women's rights. It is likely that foreign companies will bring an increased understanding of women's equality in the workplace.

The current divorce rate in Beijing and Shanghai is substantially higher than in their western counterparts. Women outside of these major eastern cities experience incredible pressure from their family and society because of cultural norms and economic restraints. This forces them to remain in unhealthy marriages. Women who are better educated and presented with better work opportunities may become emboldened to make changes in their lives.

Another important positive effect of development is healthcare. Western cities will be able to open new hospitals, raise their medical standards, and import medical devices that they previously could not afford. They will also be able to provide a form of social security and support the unemployed. Although it is difficult to discern the exact benefits that development will bring to cities in Western China, it is clear that it will raise the general standard of living. On the other hand, rapid development will have serious negative effects on parts of society and the environment.

As discussed above, migrant workers in Eastern China will reunite with their families as they are able to return to their own provinces. However, Western China's development will also attract workers that are already in Western China. Developing cities will draw on workers from throughout their province. Many people will leave their families and move several hours away in order to secure a higher paying job. Most of these workers will not be able to see their families more than two or three times a year even though their home is only a few hours away. On a larger scale, the migration from small towns to large cities will cripple the economy of these small towns and substantially affect the elderly. The PRC has a very high number of elderly people. Most of the elderly who live in these small towns will be unable or unwilling to move to a large city. As a result, they will remain in their villages while their families move away. 


\subsubsection{Environment}

Rapid development will also have serious consequences on the environment. The regulations mentioned above will likely be ineffective against pollution caused by construction and manufacturing. Other sources of pollution include the exponential increase in vehicles, energy usage, and waste. This problem may attract international attention in Sichuan because it is the home of most of the PRC's pandas. Also, Western China contains most of the PRC's scenic attractions. Pollution is already a very serious problem in Eastern China. Although Beijing moved most of its factories outside of the city center before the Beijing Olympics, ${ }^{238}$ it has been experiencing massive amounts of air pollution. ${ }^{239}$ The U.S. embassy in Beijing provides online data from its PM 2.5 sensor in order to inform and protect American citizens living in Beijing. This sensor has continuously registered a PM 2.5 level that is above hazardous. In comparison to Beijing, Yunnan has a very low level of air pollution. However, air pollution is gradually rising in Yunnan as Kunming undergoes rapid expansion. Kunming, Chongqing, Chengdu, and other Western cities will be hard-pressed to determine the balance between development and protecting their environment and citizens.

\section{Conclusion}

The PRC is the manufacturing center of the world and, even though it faces serious problems on a vast scale, it will continue to offer inexpensive and reliable manufacturing services. Foreign companies have become accustomed to manufacturing their products in the PRC and will continue to do so. Western China provides an inexpensive and reliable alternative to manufacturing in Eastern China and Southeast Asia. Furthermore, Western China has unlimited potential due to its size, large population, and stable infrastructure. Western China is also in a position to learn from Eastern China and, as Eastern China continues to develop, benefit from Eastern China's achievements.

Local regulations enacted throughout Western China demonstrate that local governments highly value development. They also indicate that local governments will promote their economies through FDI. Many foreign companies have experienced great success participating in Eastern China and, considering the rapid development of Western China, will certainly expand into Western China. The PRC is entering a new chapter in its history wherein for the first time it has both developing and developed areas. This situation has the potential to elevate the PRC to new heights. However, it will also create serious societal and environmental problems. Nonetheless, domestic and foreign interests promise to drive Western China's rapid development and transform its major cities.

\section{Copyrights}

Copyright for this article is retained by the author(s), with first publication rights granted to the journal.

This is an open-access article distributed under the terms and conditions of the Creative Commons Attribution license (http://creativecommons.org/licenses/by/3.0/).

\footnotetext{
238 See, e.g., Beijing Wipes Out Polluting Factories for the Olympics, The BeiJing Organizing Committee for the GAMES OF THE XXIX OLYMPIAD (July 27, 2006), http://en.beijing2008.cn/14/24/article212032414.shtml.

239 See Adam Jourdan, China to Spend \$16 Billion to Tackle Beijing Pollution Crisis, ReUTERS (Mar. 29, 2013), http://www.reuters.com/article/2013/03/29/us-china-pollution-investment-idUSBRE92S01420130329.
} 